Miami Nature Biotechnology Short Reports

TheScientificWorld (2001) 1 (S3), 146SR

ISSN 1532-2246; DOI 10.1100/TSW.2001.243

\title{
ROLE OF TRANSFORMING GROWTH FACTOR $\beta 1$ IN LYMPHOCYTE DEVELOPMENT AND DEATH
}

\author{
Ramireddy Bommireddy*, Ilona Ormsby, Moying Yin, and Thomas C. Doetschman \\ Department of Molecular Genetics, Biochemistry and Microbiology, University of Cincinnati \\ College of Medicine, Cincinnati, OH 45267-0524, USA \\ * bommirr@email.uc.edu
}

INTRODUCTION. Transforming growth factor $\beta 1$ (TGF $\beta 1$ ) is a polypeptide growth factor known to exert multiple functions during development and in the adult stage as well (1-2). TGF $\beta 1$ knockout mice are normal at the time of birth and do not exhibit any developmental defect. After one week of birth these mice start developing multifocal inflammatory lesions and eventually die around three weeks of age (3). Further studies revealed that T lymphocytes are the primary effectors in this phenotype (Doetschman, unpublished observation). During $\mathrm{T}$ cell development in the thymus, $\mathrm{T}$ cell progenitors undergo massive proliferation and around $95 \%$ of them undergo apoptosis. Positively selected $\mathrm{CD} 4{ }^{+} \mathrm{CD} 8^{+}$double positive $\mathrm{T}$ cells undergo thymic selection where cells that recognize self-antigens with high affinity are induced to undergo apoptosis (negative selection) (4-5). Any perturbations in the thymic education process might lead to export of self-reactive $\mathrm{T}$ cells to the periphery. In order to find the role of TGF $\beta 1$ in preventing the inflammation, we have studied the lymphocyte apoptosis and proliferation.

METHODS. Annexin-V apoptosis kit from BD-Pharmingen was used to detect apoptosis. Single cell preparations from thymus and spleen were prepared, RBCs were depleted using ammonium chloride lysis buffer, washed twice with chilled PBS and suspended in 1x binding buffer at $1 \times 10^{6} / \mathrm{ml}$. $5 \mu$ l of PE labeled annexin-V (binds to phosphatidyl serine on apoptotic cells) and $5 \mu \mathrm{l}$ of 7 -AAD (viability marker) added to $100 \mu \mathrm{l}$ of cell suspension, mixed gently and incubated at room temperature for 20 minutes in the dark. After the incubation $400 \mu \mathrm{l}$ of $1 \mathrm{x}$ binding buffer was added to the cell suspension and analyzed in a Beckman Elite flow cytometer.

Proliferation was measured using BrdU flow kit from BD-Pharmingen.

RESULTS. Analysis of apoptosis levels revealed no significant role for TGF $\beta 1$ in vivo (Fig. 1). Extent of apoptosis is varied from $10-20 \%$ in thymocytes and $20-30 \%$ in splenocytes irrespective of age, and TGF $\beta 1$ genotype. Analysis of proliferation of thymocytes revealed that $\mathrm{T}$ cells from TGF $\beta 1^{-/-}$mice are hyper responsive as assessed by tritiated thymidine and BrdU incorporation (results will be presented and discussed during poster presentation). 


\section{Apoptosis of Thymocytes and Splenocytes (Day 9)}
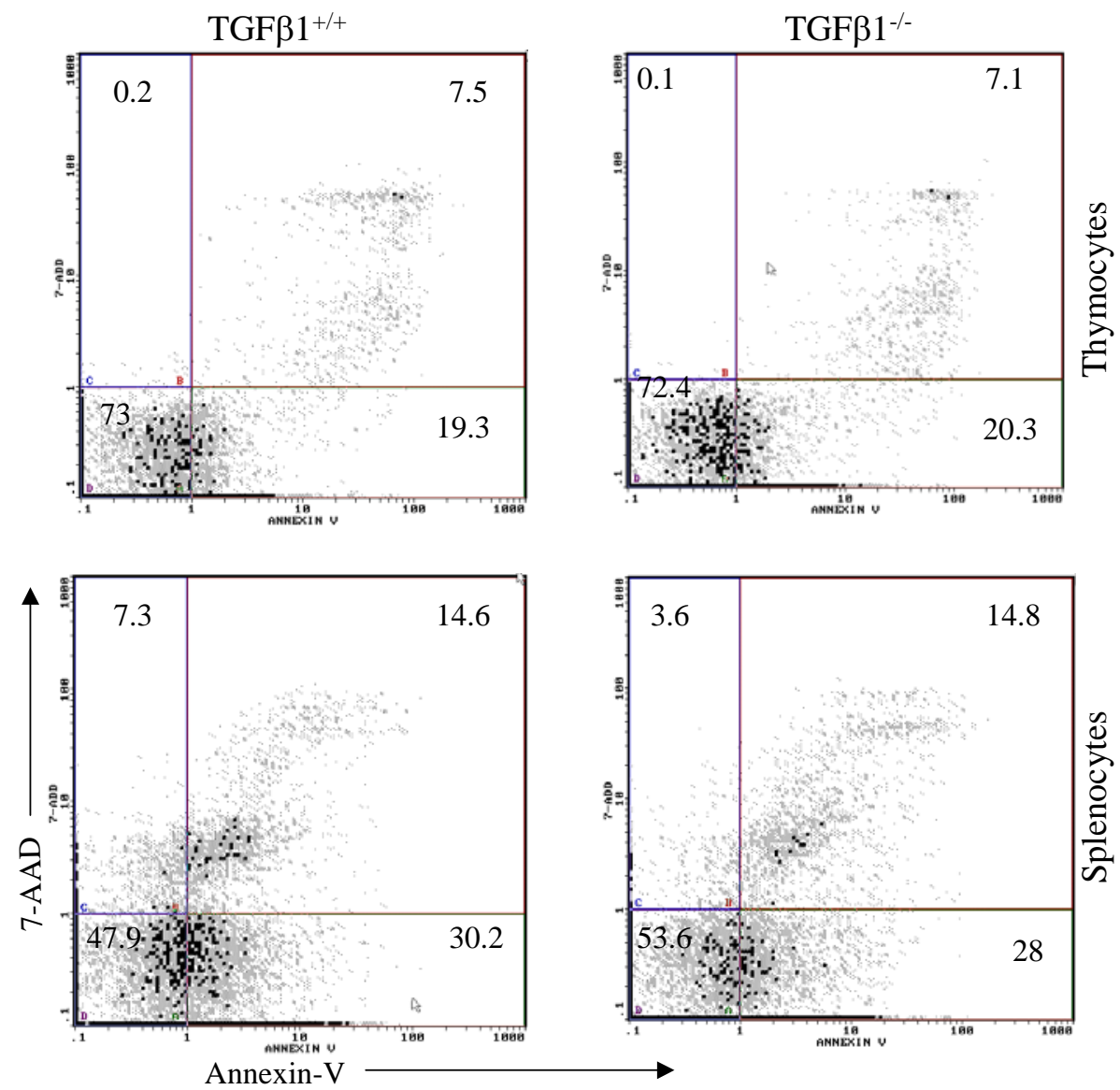

Fig. 1

DISCUSSION. Based on our observations, we propose that TGF $\beta 1$ doesn't prevent apoptosis. The minor differences observed between TGF $\beta 1^{+/+}$and TGF $\beta 1^{-/-}$lymphocytes are might be the result of hyperresponsiveness of TGF $\beta 1^{-/-} \mathrm{T}$ cells. TGF $\beta 1$ negatively regulates lymphocyte proliferative responses. Altered activation signal threshold level of lymphocytes might lead to activation and accumulation of self-reactive T cells in the periphery.

ACKNOWLEDGEMENT. This work was supported by National Institutes of Health Grants HD26471, ES05652, CA84291, AR44059 (to T.C.D.)

\section{REFERENCES.}

1. $\quad$ Massague, J., Blain, S.W, and Lo, R.S. (2000) Cell 103, 295-309

2. Massague, J. (2000) Nat. Rev. 1, 169-178

3. Shull, M.M., Ormsby, I., Kier, A.B., Pawlowski, S., Diebold, R.J., Yin, M., Allen, R., Sidman, C., Proetzel, G., Calvin, D., et al. (1992) Nature 359, 693-699 
4. Vasquez, N.J., Kaye, J., and Hedrick, S.M. (1992) J. Exp. Med. 175, 1307-1316

5. van Meerwijk, J.P., Marguerat, S., Lees, R.K., Germain, R.N., Fowlkes, B.J., and MacDonald, H.R. (1997) J. Exp. Med. 185, 377-383

6. Gong, Q., Cheng, A.M., Akk, A.M., Alberola-Ila, J., Gong, G., Pawson, T., and Chan, A.C. (2001) Nat. Immunol. 2, 29-36 


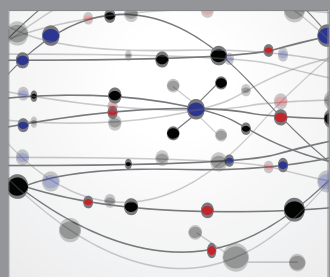

The Scientific World Journal
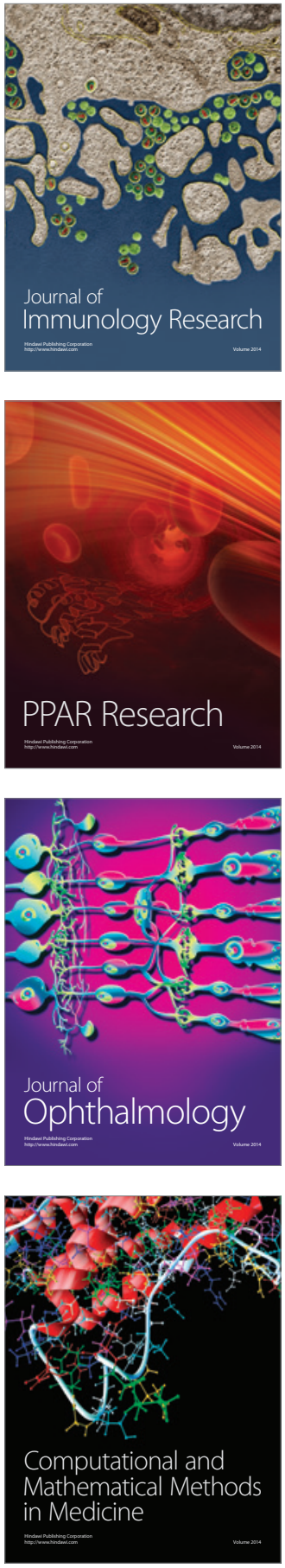

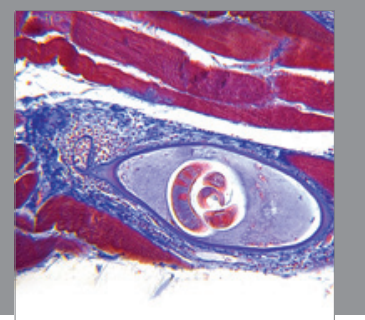

Gastroenterology

Research and Practice
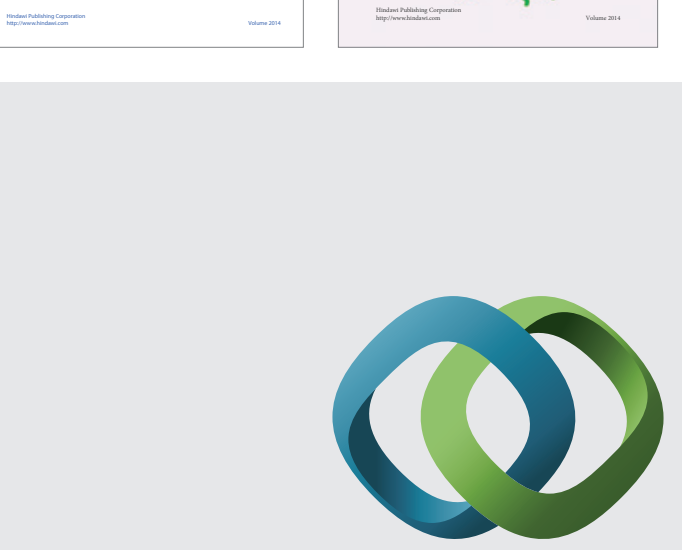

\section{Hindawi}

Submit your manuscripts at

http://www.hindawi.com
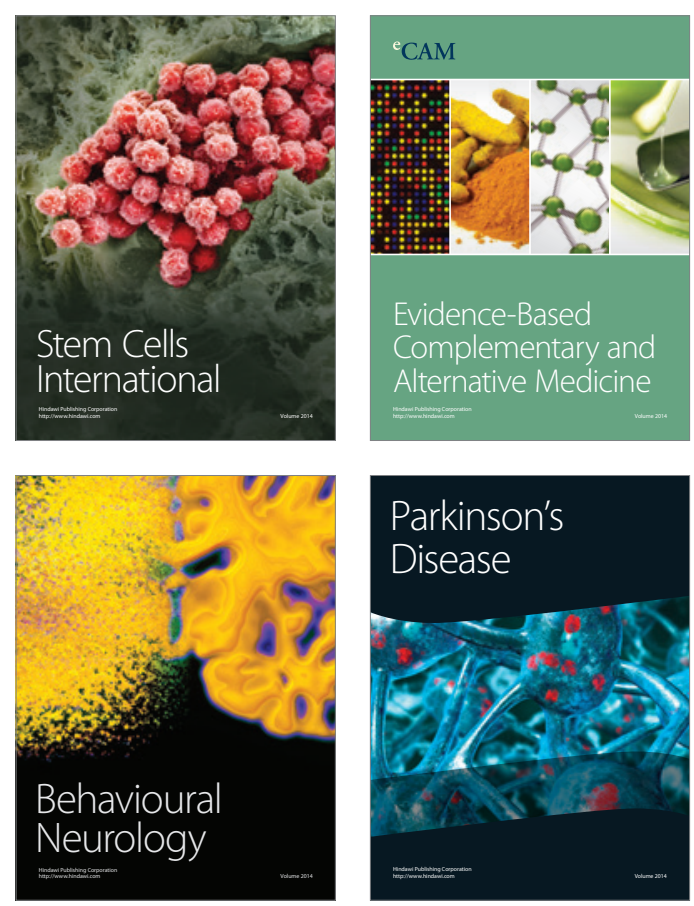

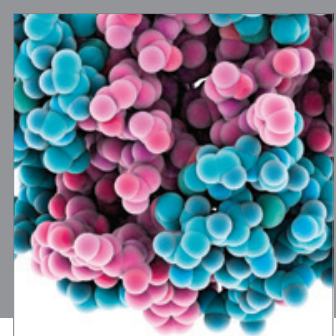

Journal of
Diabetes Research

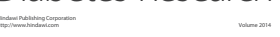

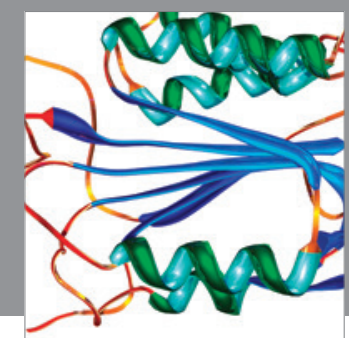

Disease Markers
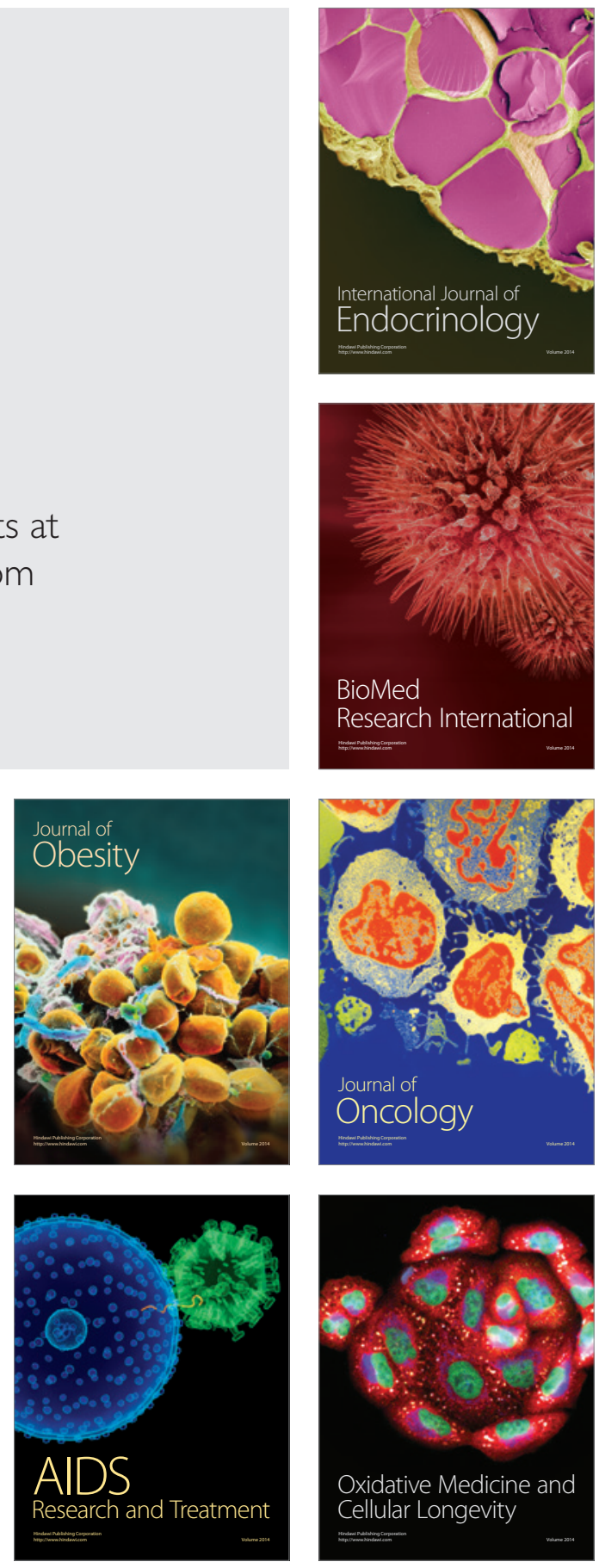